\title{
Brotherhood beyond the Ummah: Theological and socio-cultural perspectives to potential of coexistence
}

\begin{tabular}{|c|c|}
\hline \multicolumn{2}{|c|}{$\begin{array}{l}\text { Authors: } \\
\text { Serhat Kü̈cü̈k }{ }^{1} \bullet \\
\text { Özcan Güngör }{ }^{2} \text { (1) }\end{array}$} \\
\hline \multicolumn{2}{|c|}{$\begin{array}{l}\text { Affiliations: } \\
{ }^{1} \text { Department of Turkish and } \\
\text { Social Sciences Education, } \\
\text { Faculty of Education, Kocaeli } \\
\text { University, Kocaeli, Turkey }\end{array}$} \\
\hline \multicolumn{2}{|c|}{$\begin{array}{l}{ }^{2} \text { Department of Philosophy } \\
\text { and Religious Studies, } \\
\text { Faculty of İslamic Studies, } \\
\text { Ankara Y. Beyazit University, } \\
\text { Ankara, Turkey }\end{array}$} \\
\hline \multicolumn{2}{|c|}{$\begin{array}{l}\text { Corresponding author: } \\
\text { Özcan Güngör, } \\
\text { ozcangungor@yahoo.com }\end{array}$} \\
\hline $\begin{array}{l}\text { Dates: } \\
\text { Received: } 15 \\
\text { Accepted: } 20 \\
\text { Published: } 28\end{array}$ & $\begin{array}{l}\text { pr. } 2021 \\
\text { Aug. } 2021 \\
\text { Oct. } 2021\end{array}$ \\
\hline \multicolumn{2}{|c|}{$\begin{array}{l}\text { How to cite this article: } \\
\text { Küçük, S. \& Güngör, Ö., 2021, } \\
\text { 'Brotherhood beyond the } \\
\text { Ummah: Theological and } \\
\text { socio-cultural perspectives } \\
\text { to potential of coexistence', } \\
\text { HTS Teologiese Studies/ } \\
\text { Theological Studies 77(4), } \\
\text { a6745. https://doi. } \\
\text { org/10.4102/hts.v77i4.6745 }\end{array}$} \\
\hline \multicolumn{2}{|c|}{$\begin{array}{l}\text { Copyright: } \\
\text { (c) 2021. The Authors } \\
\text { Licensee: AOSIS. This } \\
\text { is licensed under the } \\
\text { Creative Commons } \\
\text { Attribution License. }\end{array}$} \\
\hline \multicolumn{2}{|l|}{ Read online: } \\
\hline 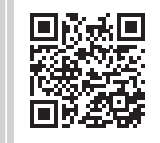 & $\begin{array}{l}\text { Scan this QR } \\
\text { code with your } \\
\text { smart phone or } \\
\text { mobile device } \\
\text { to read online. }\end{array}$ \\
\hline
\end{tabular}

When we look at a single example in the comparison of the West and the East, the ban on minarets in Switzerland or the absence of any churches in Saudi Arabia leads to incorrect conclusions. Such ideological selectivity hinders the model of coexistence. In this research study, we mentioned the possibilities, needs and minimum requirements of a coexistence model beyond the Ummah. We perform firstly (1) the description or diagnosis of the given situation, namely the determination of the problem: the political or historical, theological and cultural sources, and origin of the problem; (2) the expansion of the given situation to the paradigm from the history, the spirit of the times, theological sources and principles; and (3) solution: updating the theological, political and cultural displacements and applying them in the current context.

Contribution: This is the thesis of this paper: humans have enough theological, political, cultural and educational possibilities for a new global Convivencia for being able to realise 'together and common living'. Humans have the theological, political and cultural opportunities to realise a new global Convivencia 'living together even if not in unison' for the future.

Keywords: coexistence; Islam; Ummah; Western civilization; comparative perspectives.

\section{Introduction}

When we look at the sociological definitions of religion, it is recognised that there are substantive and functional definitions. In its substantive definition, religion expresses the experience of the sacred. In the functional definition, concrete experiences that religion brings to human life are highlighted (Horton 1960:201). At the same time as it is commonly known sociologically, even though the world and the human concepts vary according to what the religions reveal, the religions are one and only in claiming that their truth is aimed at providing happiness and peace in this world and promised salvation hereafter. Based on faith and claimed truth, while the religions establish their own 'theirs' on an individual and community scale, they also rebuild the 'others' who are seen outside of the salvation pool.

Every religion, however, aims to establish its peace, happiness and continuity, especially on the truth axis brought to its members. This desire, in a way, is the existential verification of this religious structure or formation. However, in every religious tradition, open and/or closed, indirect and/or direct, an 'other' envision gives itself up. Besides, no conflict and segregation occur just and only because of the diversity of faith, belief variety and phenomenon of religion. Becoming the subject of conflict or being made the subject of conflict of the differences in faith, belief variety and the religious phenomenon is almost always because of the individual as well as social responses and attitudes, such as strength, power, dominion, hegemony, rematch, and revenge.

From this aspect, in history, a colourful, rich and versatile West appears in front of us. The West refers to Western Europe, which had lived the medieval age with the Crusades, Renaissance and Magna Carta, on one hand, and which had established the courts of human rights and had interfered in the Bosnia massacre although it was late, on the other hand. Therefore, it can be mentioned in many aspects of the West. Or is it the West as Rudyard Kipling (1865-1936) had mentioned in his famous poem in which he had formed its basic perception?

$\mathrm{OH}$, East is East, and West is West, and never the Twain shall meet,

Till Earth and Sky stand presently at God's great Judgment Seat. (Stedman 1895) 
However, there was an Islam community that evaluates all humanity in 'Ummah', and the Islam communities, which place everything outside of them in an enemy category, and also an Islam community, which had managed to live together again after many traumas that they had endured during the Ottoman period.

In the modern age, the image has begun to take the place of reality. There are many wrong perceptions and distortions of the war, which is carried out by the two different viewpoints over the images. ${ }^{1}$ The one who controls the image also begins to control the reality. Although the Western world has more initiative and facilities, in the Islamic world, there are many institutions, groups and organisations which apply to the same perception too. In this regard, we have to remember that the relations between Islam and the West are most of the time a war of images (Kalın 2007:17). ${ }^{2}$ Will we surrender to this perception for the life model beyond Ummah, or will we take the initiative and be the pioneer of change?

We can start from here: just as the 1400 years of Islamic history is too colourful, rich and versatile to be reduced to a single word or concept, in the same way Western civilisation has many differences, colours and tones in itself too.

In this context, in the theological, political and cultural world of the Islamic societies, one of the most important concepts, which forms its own self-conception, is 'Ummah'. However, 'the Ummah' concept has undergone a change of meaning in modern times and the Ummah has mostly become a theological and political concept in religion. Yet in the early period of the birth of Islam, the Ummah description in the Medina Record of the Prophet was pointing to a wider ontological and cultural world. As explained later, accordingly not only Muslims but also the members of different religions that accept to live with Muslims, which are safely connected to the Muslim society within the framework of cohabitation, ethics and law had been accepted as an inseparable part of the Ummah, so it had been formulated by the Prophet in person in being an Ummah, a social situation (Hasan 2006:314-322).

With global problems worsening gradually, it makes it difficult to live together, which is exacerbated by the homogenisation and pluralisation of communities. In response, this study offers a model of living together beyond the Ummah too. In this study, we mentioned the possibilities, needs and minimum requirements of a living together model beyond the Ummah. We perform, firstly, (1) the description or diagnosis of the given situation, determination of the problem: the political or historical, theological and cultural

1.These words should be read as general inferences, keeping in mind the diversity within the West and the Islamic world.

2.The concept of the West, which the author positions against Islam, does not mean a homogeneous group of countries and nations. Instead, the concept of the West imagines a living culture that has evolved with Rome and modern European imagines a living culture that has evolved with Rome and modern European
civilization, taking its roots from Athens. Similarly, the concept of Islam corresponds to a civilization that takes its roots from the Qur'an and Sunnah, which are the to a civilization that takes its roots from the Qur'an and Sunnah, which are the
principles of divine religion, in different geographies from Mecca to Andalusia principles of divine
(Kalın 2007:25-40). sources, and origins of the problem. (2) Secondly, we perform the expansion of the given situation to the paradigm from the history, the spirit of the times, theological sources and principles. (3) Thirdly, we provide the solution: updating of theological, political and cultural displacements and applying them in the current context. Thesis of this study: human beings have enough theological, political and cultural possibilities for a new global Convivencia, for being able to realise 'together and common living'. We call it 'even if not in unison' because according to the thesis of the study the claim of 'unity' may damage pluralism by indoctrinating homogeneity, while 'togetherness' approves the differences as they are and prioritises pluralism (Şimşek 2016:374-376).

\section{The conceptual approach to 'Ummah' with its beyond Ummah meaning}

The term 'Ummah' refers to community, way, religion and generation (Bulut 2012:308), and as a term, it is used for the human community living together as a result of its own will or an obligation in the same place, at the same time or by obeying the same religion (Ünal 2016:11). Besides this, based on the analysis of the Qur'an, factors such as integration around the same purpose (Surah 28:23.), having common beliefs fed from the same sources (Surah 43:22-23; Surah 16:93) and living within a specific time period (Surah 7:34) are viewed as being an Ummah.

Therefore, Ummah is a religious concept, which combines the Muslims, makes them brothers and equalizes the ethnic structures, and it is also a political concept. This concept is used in the political space for all humans who are living in the same country without making any religious separation from time to time. As a result, some Arab countries use 'Meclis-i Umme' (Congress of Ummah) instead of Parliament. Being a Muslim is not a condition required to enter the 'Meclis-i Umme'. In other words, in addition to the religious displacements of the Ummah concept, we have to tackle the political and cultural displacements of it.

When it is carefully examined, the Holy Qur'an places the animals in the same category as an Ummah in addition to the unit composed of the humans, which gather thoughts and ideals. For example, reptiles or flying animals are each an Ummah in itself (Surah 6:38). Indeed, in the hadiths, the animals are defined as one each Ummah or type too (Muslum, Selam, 148; Al-tirmidhi, Sayd, 16; Ibn Majah, Sayd, 2; Ünal 2016).

The Ummah, in the largest circle, is the name of the set composed of humans, which are tied to the same emotions and values in accordance with the principle of Tawhid, in terms of the same basic structure and target, and the second set contains the Ummah of Muhammad, which is the most prominent according to the majority. Also, there are subgroups within the Ummah of Muhammad. The existence of an invitation group that is ordering the good and making 
people avoid evil can be provided as an example for this. According to this concept, Ummah has a range of meanings surrounding the meanings, such as (1) live communities, (2) human communities, (3) the community tied to the Prophet, (4) the sub-groups in the Prophet's Ummah and (5) the persons who had left big values to the history with their actions (Öztürk 2011:453-454).

After the hejira (immigration), in the pact (Medina Document or Pact of Medina) which the Prophet Muhammad had made to ensure the commitment of the people of Medina against the polytheists of Mecca with all groups in this city, including the People of the Book, being mentioned of the Jewish tribes as 'Ummah' together with the Muslims gives a hint about the scope of the concept. Indeed, from this point of view, Watt submits that the 'Ummah' is related to the believers rather than Muslims, and the Medina Jews are deemed to be in the Ummah of Muhammad (Watt 1956:240-241). However nowadays, this wide meaning of this concept has been restricted because of many historical, cultural and political reasons, and it has become a barrier in front of a common maruf (the good one) and tearufe (communication or meeting).

\section{The theological, political and cultural roots of the problem}

\section{The theological factors complicating the life beyond Ummah}

Islam had been perceived as a theological challenge by the Christian world from the moment it had appeared on the stage of history. The emphasis on the belief of one God made by the Qur'an was the thesis confirming its being the last link of the Abrahamic tradition. Islam was not content with only again placing the oneness belief on a sound basis. At the same time, Islam directed significant criticism against Judaism and Christianity on a theological level. Islam blamed Judaism for making the oneness belief the religion of one nation and thereby limiting the oneness belief, and it also blamed especially Christianity for its trinity belief because it damaged the oneness belief. However, while Islam was making this criticism, it legally protected Judaism and Christianity by providing them the status of the People of the Book, which have not been found in other world religions (Kalın 2007:45-56; Yaman 2015:19-21).

Islam had, therefore, brought a legal place to its 'religious other' in its own religious-social order, although it was the first time in history there is nothing to be surprised by this. Because as a religion, Islam was aware of the different religious experiences from the beginning. The references made by the Qur'an to the prophets who are also accepted by Judaism and Christianity confirm this. Spreading the first period of Muslims into a different religious and cultural environment in a very short time shows us that the Islamic societies had developed a more comprehensive, flexible, and confident demeanour on the issue of the 'religious other'.
Judaism and Christianity produced answers with maintaining a stance against these theological criticisms and approaches of Islam. As we do not go into the details of these answers, we can say that mostly many propagandas had been produced on the theological level and had been served to the public as the Prophet Muhammad was a 'false' prophet, the Qur'an had been collected from around at random and it was a story and nonsense, the Muslims were 'heretical Christians' (Newman \& Sivan 1980:203). As a result, it is not surprising to find inappropriate analogies about the Prophet of Islam still present today in many popular books and Hollywood movies, as was present in the past. As an example, a well-known production that made a hit with the world public opinion is the film 'The Innocence of Muslims' (2012) directed by Nakoula Basseley Nakoula, an EgyptianAmerican. Another striking example is 'The Stone Merchant' directed by Renzo Martinelli.

In the theological sense, the arguments developed by Christians or Jews against Islam constitute one aspect of inter-religious relations. In addition, there are objections to Christianity in Islamic theology. Firstly, it is stated that Christianity is a distorted true religion. In addition, in the context of God's conceptions, criticism has been brought about the trinity, incarnation, putting the prophetic aspect of the prophet Jesus in the background, belief in redemption, changing the form of worship, forbidden pork and alcohol (Arslan 2010:42-43; Sarıkaya 2020:365).

\section{The political factors complicating the life beyond Ummah}

The rapid spread of the political boundaries of Islam and gaining dominance over the lands, which were under the control of the Byzantine Empire before, redirected Islam from being a theological challenge and caused Islam to be perceived as a political threat. The conversion movements, which were keeping abreast of this geographic expansion, provided Islamisation of Central Asia, North Africa and Anatolia in a short time. It is not hard to see the historical importance of this: the lands that were lost to the Muslims formed a basis to build a new culture and civilisation at the same time. In other words, the problem was not a single geographical and military expansion matter. However, it was not difficult to understand the trauma and anxiety of the members of other religions composed of the military and geographical expansion.

Especially the Crusades, which had been a series of wars between the years 1095 and 1270, had raised the tension between Islam and the West to an advanced stage. Pope Urban II who had made a speech and had called for mobilisation in 1095 in Le Puy city of France, invited the whole Europe to liberate the holy lands from the 'irreligious heretics', in other words, the Muslims. The Pope, in his speech, was preaching that the holy lands, including Jerusalem, belonged to the Christians, Jesus was born and baptised here, the first church was built here and these lands had to be taken away from the Muslims. The failure in large 
measure of these mobilisations, which had been carried out towards the end of the medieval age, led to the Catholic Church losing its prestige in the sight of the public (Head \& Landes 1992:26-27; Kalın 2007:72).

One of the other important political breaking points between Islam and the West is the Andalusia disaster. In Andalusia, which is the South of today's Spain, Muslims had produced important works on science, thought and art, and had built a civil society. This rich culture and civilisation which had continued until 1492, had ended with the expulsion of the Muslims from Europe. During this expulsion process, the Inquisition Court was established, convicting those who did not accept Christianity, and their property was plundered. (Özdemir 1997:252-253).

In fact, one of the most important matters which makes the coexistence beyond the Ummah difficult is the attack of the Western powers and the crisis managed by the secular-religious dictators supported by them in this region. It is just like having the role of the Romans and the supporters of Herod Antipas in the raise of the Zealots. At the source of the atrocity and terrorism performed by the Zealots, there was the role of its restricting the freedom area of the people from the inside and the outside as far as possible.

In this context, it should be expressed that as the resistance against the policies of the West in the Islamic world increases, this resistance turns to a great motivation and it is being substituted for genuine piety. Islamist ideologists tend to define Islam mostly as a political ideology, which will allow Muslims to defeat the world system under the dominance of the West, not as the way going to Allah's mercy and the eternal salvation (Akyol 2011:153).

The continuing persecution under the administration of the Islamic world in socio-political meaning, the oppressive governments, the problems like not being able to be demilitarised, not being able to be politicised, are creating the situation of absence of the possibility of politics, which is the area of the individual and social requests. The governments, especially in the nearby countries (e.g. democracy and degrees of freedom of Syria can be seen in reports, such as Freedom in the World and World Democracy Index), which continue their existence by both leading on the 'legitimacy' halo installed by them and leading on the material base of the local and international power, insist on an oppressive management style. In addition, this consumes all of the civil courage and rightlike demilitarisation and politicisation, being able to take civil initiative. Where there is no civil structure and social politics, there is an authoritarian and mostly a totalitarian structure and status. Being supported of such environments partially or openly by the West makes the possible political tools in Islamic thought tradition ineffective.

\section{The cultural approaches complicating the life beyond Ummah}

Getting on the stage of the history of Islam as being a culture and civilisation, corresponds to a new phase of the IslamWest relations. The Islamic world which had made big moves in the areas of philosophy, science, art, urban development, trade, health, and education, had got out of being a local religious identity from the 18th century and had become the centre of a universal culture and civilisation (Sezgin 2011). The unexpected success of the Islamic world in the areas of science and culture had propelled the Medieval Western world to a larger confusion over the issue of 'Islam problem'.

The success on these areas of Islam which was perceived as being a deviant Christian denomination on one hand, and on the other hand, as being 'sword religious' had already been perceived by the West during the Middle Ages as not being a success due to Islam as a religion, but as being a success 'despite Islam'. In the eyes of an average European, Islam was a religion with violence in its core, which was extended by the sword, was irrational, was whipping the worldly and sensual desires of its followers, was targeting the assimilation of the other and in the final analysis, destroying it. Being able to see the deep effect of this image in European awareness, it is enough to look at a series of cultural products from the depiction of (the or a) harem in the 19th-century European literature to the Hollywood movies like Siege and True Lies. The message lying behind this fiction is always the same: Islam is a threat that targets the existence of the West in itself. This fear of Islam in the subconscious (Islamophobia) mind, as it can be expected, became stronger after the September 11 attacks.

In fact, the continuity in perception of the Prophet Muhammad between being blamed of being a 'false prophet' by the Umayyad officer St. John, who had written the first anti-Islam polemics in the eighth century, and being called a 'terrrorist' by the American evangelist Jerry Falwell in the 2000s, is remarkable. It is possible to perceive this up to some extent. Interestingly, there were a minimum of 13 cities in the Islamic world which had a population of over 50,000 in 800 A.C., while there was only one city - Rome - in Europe. Here, we can express that the people managed to live the highest level of freedom and individualism in the cities by living together (Fuller 2010:247).

Dante, who is accepted as being the founder of the Italian literature and Renaissance movement, had gained a huge reputation with his work named 'Divine Comedy'. ${ }^{3}$ This work consists of three parts: Heaven, Hell and Purgatory. For Muslims, the most important place of this work is that the eighth ring of hell consists of nine rings. Dante evaluates the Prophet Muhammad in this ring as being the divider because he had founded a new religion while there was Christianity. Another important personage that can be found in this ring is Ali, the groom and the cousin of the Prophet Muhammad.

3.See S. Gilson, Reading Dante in Renaissance Italy: Florence, Venice and the "Divine Poet' and Ernest L. Fortin, Marc A. LePain: Dissent and Philosophy in the Middle Ages: Dante and His Precursors (Applications of Political Theory). 
Dante was trying to dissipate his anger against Islam by throwing the founder of this religion and his faithful followers, who has said so in the part of his work, which had caused tension and created a scandal between the West and the Islamic world:

(Someone else penalized in hell tells Dante...)

Look how Muhammad were also crippled!

The man going in front of him tearingly is Ali

His face is slashed from his chin to the top. (Dante 1998:232)

Similarly, when the themes of harem and concubines evoke the sexuality in A Thousand and One Nights, which had been translated into Western languages from the beginning of the 18th century, introduced ideas like the above about Islam, the resulting thought was not labeled as 'Islamophobia', which shows that there is a long history of anti-Islamic thought.

\section{The expansion of the given situation to the alternative paradigm}

\section{The boundaries of the theological possibilities in the context of good examples}

Islam, which had revealed the principles of living together with many faith groups, had been based on tolerance and religious freedom. Words such as af and safh, which express tolerance, had been used in nearly 25 verses of the Qur'an (Çiçek 2008:22). In addition, Islam had attributed a special status to Judaism and Christianity. Firstly, they are Allah's religions. Their founders on earth, Abraham, Moses, David and Jesus, are the prophets of Allah. It is prohibited not to believe them, even to differentiate between them (Esen 2010):

[O]ur God and your God is one (the same deity) (Surah, 29:46; Surah, 46:15) Allah, had described the Prophet Muhammad and the believers as 'those who believe in all of the inspired thing by Allah' and 'those who don't make the distinction between the prophets of Allah'. (Surah, 2:285; Faruki 2011:110)

Islam, which puts Judaism and Christianity in a different place because of the common heritage, also did not leave us unguided about living together with other religions. Firstly, it had been emphasised that there is an alerter of every nation, which will be drawn to the account. 'We don't torment unless we sent a prophet' (Surah, 17:15). Also, it is defined that there is an alerter of every nation: 'We have sent you with right as being bearer of good tidings and alerter. There was necessarily an alerter (a prophet) for every nation' (Surah 35:24). 'Indeed we sent prophets before you too. There are persons among them who told you their stories, also the persons whom we didn't notify you their statuses' (Surah 40:78). 'We sent prophets as being bearer of good things and protector so that people do not have excuses against Allah after that! Allah has honor and wisdom' (Surah 4:165). Therefore, Islam creates a proper base for relation with all humans, especially for Jews and Christians whose prophets are approved in the Qur'an (Faruki 2011:116).
Perceptibly, the Qur'an remarks the common points on the belief, spirituality and good values of the People of the Book to the Muslims (Surah 3:113-115). Theologically, there are many common points in terms of the teachings of Islam with the People of the Book. Firstly, unlike the ancient Egyptians, Indians and Chinese, it is immanent to the realm with an ontic reality different from God's creatures. Secondly, the purpose of creation of the humans is serving Allah's earth, His own property. Thirdly, the relationship between Allah and His creatures or Allah's willpower being the core of the inspiration and expressing of it in the frameworks of law, needs and moral directives. Fourthly, humans have the power of transforming the property created by Allah into the direction of His willpower. Fifthly, ending of the human's obedience to the divine order with happiness and peace; otherwise with pain and damnation and so with merging the earthly and the cosmic justice. Islam called the central religious tradition of the Semitic people 'renunciate' and described itself with it. The Islamic Hanif concept should not be confused with Karl Rahner's 'Anonymous Christians' (Rahner 1974). 'Renunciate' is not a discovery of a modern theologian who had suffered because of the exclusivist claims of the Church about the divine blessing but also a category of the Qur'an. For 14 centuries, it has been processed in the thought system of Islam. The ones who are imputed with being 'Hanif' are the examples of faith and magnanimity, they are the most glorious representatives of the religious life (Faruki 2011:112).

\section{The limits of the political opportunities in the context of the good examples}

In pre-Islamic Medina, three major Jewish tribes, namely, Beni Kaynuka, Beni Nadir and Beni Kurayza, and other Jewish tribes consisting of small family units, constituted nearly half of the city's population. Apart from these, there were polytheist groups and very few Christians who were living in Medina too (Munt 2014:44-47). The Prophet Muhammad had signed the Pact of Medina in Yesrib with the other people in order to ensure political and social union (İbn Hişâm 1955:50). The Pact of Medina had been applied perceptibly from 622 until 632 and it had gone down in history with a legal value as being a kind of constitutional law (Okuyan 2008:160). In the second and twenty-fifth items of the agreement, Muslims, Jews, and the polytheists were mentioned with 'Ummah' adjective, also a political partnership was mentioned (Lecker 2004:3).

The Prophet Muhammad had documented each of the articles of the Pact of Medina with many verses from the Qur'an as a manifestation of the Qur'an. In various articles of the Pact (Article 37, 37A, 38, 40, 44) the obligations (if needed), such as helping others of different faiths, sharing, loading the economic responsibility together and not encroaching each other's rights had been expressed too (Okuyan 2008:161).

Also, Prophet Muhammad had provided many examples of the coexistence beyond the Ummah. According to a rumour, 
the Prophet Muhammad had given a charity to one of the Jewish families, he had accepted from non-Muslims and also wanted help from non-Muslims in war and peace. Especially this even existing in the resources is extremely striking: When a funeral was passing by the Prophet Muhammad, he stood up for the funeral, when it is said '[t]his is a Jewish funeral', he answered as '[i]s this not a life?' (Y1lmaz 1998:7-8).

When the Prophet Muhammad sent a message to the King of Himyarite South of the Arabian Peninsula, he laid down a condition not to make any intervention in the old religions of the people who wanted to stay as Jews and Christians; also, in the message which he gave to the Necran Christians, he declared that he would be the guarantor in-person to their assets, lives, religious life and practices, families and temples. Indeed, when Amr Ibn al-' AAS' (d. 43/664), who was one of the companions of the Prophet Muhammad, was Egypt's Governor, he built the Macarius Church in Alexandria, and during the mission period of Maslamahb Mahled (47-62/667-681) he allowed a monastery in Fustat (Cairo) to be built.

In $620 \mathrm{AD}$, shortly after the conquest of Makkah, the Necran Christians in Yemen sent a committee, which was composed of their tribal leaders, to visit the Prophet Muhammad in Medina. Their goal was to clarify their position in front of the Islamic State and to clarify the position of the Islamic State in front of them. Their delegations were the guests of the Prophet Muhammad; he accepted them in his house and his mosque. He invited them to Islam, which some of them immediately accepted. Some of them chose to join the Islamic State as Christians. The Prophet Muhammad established a Christian Ummah for them in the Islamic State next to the Jewish and Muslim Ummahs (Faruki 2011:125).

Similarly, the Christian State Ethiopia, which had protected the first Muslim immigrants from the wrath of Mecca, and had continued a peace and friendship agreement with the Islamic State during the time of the Prophet Muhammad, had been excluded from the expansion plans of the Islamic State (Faruki 2011:125).

Muhammad had provided the following guaranteed message to the people of Necran, who were living in South Arabia:

[T]here is security of Allah and the debit/guarantory of Muhammad on the goods of Necran and its environment, their religions, churches and few-many, anything in their hands. Their priests, monks, and oracles cannot be discharged. (Ünalan, Öztürk 2007:27)

He was so friendly to the non-Muslims that he had once allocated his own masjid as a place for the rites of the Christian committee that was staying in Medina during that time. The Qur'an declares that even it does not confirm the rites made in them, the temples of every religion are under protection (Surah 22:40). After Khaybar was conquered by the Prophet Muhammad, he had left the temples of the Jews as they were, and had returned the copies of the Old Testament to them (Yaman 2015:25-26).

During the time of Muawiyah, the existence of nearly 200 Christians in Madinah's security force is one of the typical features of this period. Besides, the first Muslims had supported the Byzantines against the Sasanians, because the Byzantines were from the People of the Book (Surah 30:1-3).

Andalusia Umayyads, during the period of Hakem I, had established a guard's unit composed of 5000 Christian soldiers. In this regard, it is possible to offer many examples from Andalusia. The important point here is to be of the religious factor not much or only a determining factor in the establishment of an army. That is why the Christian soldiers were charged in the army by the Muslim administrators, and also the Christian soldiers did not consider it harmful to fight on the same side with the Muslims against their own co-religionists (Aydin 2009:89).

Since the invasion of Babylon in 586 BC, for the first time in history the Jews could form their lives according to the Torah by being citizens of the Islamic State. It was the first time that a non-Jewish state placed executive power into the service of a Rabbi or Hebrew Tribunal. Under the auspices of Islam, Judaism and the Hebrew language lived their golden age. Hebrew gained its first grammar, the Torah gained its law science, Jewish literature gained its lyrical poetry and Jewish philosophy found the Musa b. Meymun, of which the first 13 rules had been expressed in Arabic and had defined the Jewish faith and identity (Faruki 2011:125).

It is possible to view many similar examples in Turkish-Islam history too. For example, on a Friday, in a fight between a Muslim from the vassal of Germiya Turkish Seignior Alisir and a Christian from the vassal of Bilecik Greek leader, Osman Bey had adjudicated in favour of the Christian person (Kazıc1 1998:106-107).

Again in the 14th century, in a provision sent to the Greek Governor with Sivas and Divrigi Kadi (Muslim Judge), it was declared that in a Christian village, Divrigi, two Muslims named Mehmet and Himmet had been unfair to the non-Muslim subjects and had taken extra money from the villagers, and it was ordered to take their emancipation zones from their hands to be never given back again and the restitution of the rights of the non-Muslims was ordered too. A similar situation was about a Timariot, who was preventing the rites of the Armenian citizens and the education of their children, and the Timariot had been punished with a hard labour penalty (Kazıc1 1998:109).

During the period when the Jews were killed and the courts of the Inquisition were murderous, the people of different 
religions under the Ottoman administration were living in peace and harmony. When the Ottomans founded their nationality, it was the first nation that put religious freedom as its basic foundation (Kazıc1 1998:111).

The expression of the Syriac historian Patrik Michael confirms the religious tolerance of the Ottoman Empire:

$[B]$ ecause the Turks who had invaded most of the homelands belonging to the Christians, do not have any idea about the holy secrets (Trinity) and consider Christianity as an error, they do not need to get information about the religious dogmas (Christianity), they do not interfere in the religion and belief of anyone opposite to the actions of the evil and pervert Greeks and they do nt think to perform any oppression and tyranny. (Baş 2011:50)

Fatih (the Conqueror), had provided every convenience to the non-Muslim religious functionaries which had come to his home from another country. He had given importance to their living in peace and well-being in his country. In Bosnia, he had protected the Latin priests by sending an edict to his subject with sharp words (Kazıc1 1998:112).

Not only for religion, customs and training issues but also in terms of economy, the welfare of the non-Muslims had been valued. Ottoman had changed the day of the district bazaar which occured on Sundays, because the Christians did not work on Sundays, in so doing trying not to inconvenience them (Kazıc1 1998:112).

It should be stated that today, there are no conflicts between Muslims and members of other religions to destroy the other in daily life. ${ }^{4}$ However, it is a fact that there are local conflicts in many parts of the world - not only in areas where Muslim societies exist. ${ }^{5}$ However, if we talk about statistics, the majority of those directly affected by these attacks carried out by terrorist organisations under the name of 'global jihad' are Muslim people. Likewise, global terrorist acts do not have a single addressee. ${ }^{6}$ It is also known that terrorist groups, who shape their identity within the framework of a certain belief or interpretation of that belief, carried out violent acts against people of other faiths. ${ }^{7}$

4.The most obvious examples of this are Muslims living or visiting the West and people from other religions living in Islamic countries or visiting as tourists. Today, with a population of 25 million in the West, $1 \mathrm{slam}$ is the religion with the soday, with a population of 25 million in the West, Islam is the religion with the second largest number of believers (Emin 2018). At the same time, a large number of people from other religions live in countries where the majority of the population is Muslim (Indonesia, Pakistan, Turkey, etc.) (Diamant 2019). Apart from those residin in Muslim countries (before the COVID-19 pandemic), Middle Eastern countrie hosted 60 million tourists in 2018 (UNWTO 2019:14)

5.Regional conflicts are encountered in almost all of the world. Today, the mos mentioned conflict areas include the Ukraine-Donbass region in Europe, the MexicanUS border in South America and the internal conflict in Venezuela, the North-South Korean Crisis in Asia and the Pacific, the China Sea Crisis, the conflicts in Sahara Africa, Yemen, Libya, and so on are the conflicts in the Middle East (CFR 2021). Conflicts, especially in the Muslim geography, are attacks by terrorist organisations and interventions by regional and non-regional actors through third parties (Deniz 2016).

6.According to the Global Terrorism Index, almost all of the 10 countries most affected by terrorist incidents are those with a Muslim population (IEP 2020:18).

7.See attack on a synagogue in Germany, https://tr.euronews.com/2019/10/09/ almanya-n-halle-kentinde-meydana-gelen-silahli-saldirida-en-az-iki-kisi-yasaminiyitirdi; attack on two mosques in New Zealand https://www.aa.com.tr/tr/pg/fotogaleri/yeni-zelanda-da-2-camiye-saldiri-; attack on a church in Indonesia https:// www.bbc.com/turkce/haberler-dunya-56560684.

\section{The limits of the cultural or historical possibilities in the context of good examples}

After conquering Mecca, the Prophet Muhammad removed all of the idols in Kaaba, but only the frescoes of Jesus and Mary had been kept separate. Because the Qur'an has a deep respect for both of them (Lewis 2003:40). In spite of the severe reaction against polytheism, when Christianity and Judaism came into question, it was easy to meet at common points.

During the Rashidun caliphate, Abu Bakr had guaranteed the non-Muslims in Himyar with these words:

[I]f an old man becomes unable to work or has an accident or becomes poor as he was rich before and his co-religionists also start to give alms to him, this person will be tax-free as long as he lives in the Islamic State and his breadwinning shall be provided from the State Treasury. (Yaman 2015:25)

Both the Umayyad and Abbasid states, as well as in later periods, religious discussions took place amongst the Christian and Jewish clergymen and the Muslim clergymen in the presence of government officials; sometimes these discussions continued for days in public (Baş 2011:41).

Although Yuhanna Dimeski was the person who had written the most serious refutation against Islam, he was known as being the first Christian theologian and after the death of his father, who had conducted his financial duties in Umayyad Palace for many years during the period of Khalifa Abdülmelik b. Lijian (684-705) and his son Walid b. Abdulmalik (705-715), he had conducted the duty of his father (Baş 2011:47).

The Muslims had demonstrated their vast tolerance to the people after they conquered Andalusia too. The Christian and Jewish temples had been left open, their activities had not been interrupted, and even more free environment had been provided. So much so that during this period, with the contributions of Christians, Jews and Muslims in Andalusia, a religion and civilization experience called 'convivencia', 'coexistence' was actually experienced as a mutual tool to achieve much better (Aydin 2009:26; Hillgarth 1985:33; Özdemir 1997).

For non-Muslims, practices not prohibited by their religion, such as manufacturing and drinking alcoholic beverages, feeding and eating pigs, and marrying relatives, were allowed in Islamic States (Yaman 2015:29). In the city of Córdoba, the Jewish quarter was located adjacent to the Great Mosque. The Muslim and Jewish cemeteries are side by side, and there was only a thin path between them. Again in the same city, the Muslims and the Christians had shared for some time San Vicente Church as a worship place, as half of it belonged to Christians and the other half belonged to the Muslims. In one of the city's main entrances, there was a statue representing the Virgin Mary (Aydin 2009:26; Bas 2011:49-50; Özdemir 1997). 
A large part of the soldiers who conquered the Muslim Andalusia came here unmarried and settled. Since the first days of the conquest, these soldiers began to marry non-Muslim women. Moreover, one researcher claims that two and a half centuries after the conquest, the Andalusian Caliph of the Umayyad Hisam II carried a rate of only $0.09 \%$ Arab blood. The important side of these marriages was that some of the Christian women, who were the wives of Muslim men, had continued to remain faithful to their own religion after their marriage. Thus, Christians had taken a place at all levels of the army, at all levels of the state, and even near the caliphs as being the sultana (Özdemir 1992:90).

It is possible to build a better future from now with examples of this in history too. For example, when the Muslim traveller Ibn Cubey from Andalusia had visited Jerusalem, he had mentioned 'the Muslims living in peace under the administration of non-Muslims' and he had said that their obligations were 'to give half of their products and to pay taxes as one dinar and a seven-carat' and he had added: 'The misfortune of the Muslims is being suffered because of the injustice of the managers in the countries which are directed by their co-religionists'. Whereas here, the Muslims are pleased because of the behaviors of the non-Muslim whose justice they can always trust (Courbage \& Fargues 1997:48).

\section{Theological, political and cultural construction of the ground where the solution will be produced updating the theological resources}

In Islam, it would never be advised to make war over the religion with people even if they are not subject to any revelation. On the contrary, ' $\mathrm{t}] \mathrm{o}$ you be your Way, and to me mine'. (Al-Surah, 109:6) was ordered and everyone was bestowed the freedom to live according to his or her own religion.

Islam attributed value to humans because of just being a human. Many verses of the Qur'an and Hadiths revealed that all people came into existence from Adam and they are innately valuable, they were created as the most honourable creature of earth, each of them are Allah's caliphs because of the fact that they all were tasked with performing the will of Almighty Allah, and these are not acquired with belonging to a race or religion, they are already available in human identities by nature. This truth is expressed in Islamic tradition with the concept of 'Inviolability of Humanity' (Yaman 2015:13). For this reason:

[I]f any one slew a person, it would be as if he slew the whole people: and if any one saved a life, it would be as if he saved the life of the whole people. (Surah 5:32)

Islam will continue to value old prophets and followers, even if Jews and Christians will end or decrease their loyalties (Surah 3:68). Christians are aggrandised in the Qur'an because of their ascetics, servility and fears, and they are described as the nearest to Muslims amongst all believers
(Surah 5:82). Allah ordered Muslims to invoke Jews and Christians with the following words:

[O] People of the Book! Come to common terms as between us and you: That we worship none but Allah. That we associate no partners with him. That we erect not, from among ourselves, Lords and patrons other than Allah. (Surah 3:64)

This common tradition expressed in the Qur'an, was explained by the Prophet as follows:

$[M]$ y position (in) prophets' chain looks like that: A man made a house and decorated (this) building but a brick remained missing. In this condition, the people started to wander this building and they liked it and said that 'would that this brick was in its place...'. Here, I am that brick. I am the last one of the prophets. (Miras 1998:9/255)

As can be seen above, Islam regards itself as a confirmation of the same truth presented by all previous prophets of Jews and Christianity other than a brand new religion in history (Faruki 2011:111).

It would be better to state the following in order not to get the wrong impression that living together at peace and making religious notification cannot be side-by-side. Every universal-natured religion wants to be spread. Islam wants to convey its call to the entire humanity. Its method would never be sword, bullying and pressure when doing this. ${ }^{8}$ The Holy Qur'an, when it is calling people to faith with its beauty, first invites them to think and question. 'Invite (all) to the Way of thy Lord with wisdom and beautiful preaching; and argue with them in ways that are best and most gracious' (Surah 16:125). Let there be no compulsion in religion. Allah ordered 'there is no compulsion in religion' (Surah 2:256). If a nonMuslim still does not believe after being invited, Muslims should leave this situation to Allah. The Prophet sets Christians who do not confirm to his call that he made in and of itself free. He, then, receives guidance that benefits his own soul: but he that strays injures his own soul (Surah 39:41).

Besides, some customs, which are considered as theological, are exactly the traditional perseverative customs and they are not resulting from religion, for example, circumcision of women. The findings obtained from excavations in Egypt revealed that there had been such a custom before Islam, Christianity, and even written history. As this custom exists in Ethiopia whose majority is Christian, as well as Animists, even a Jewish tribe living in the mountains of northeastern Africa continues this bad custom. As it is seen, a custom, which seems related to Islam, is an application being sustained with traditions based on centuries (Althaus 1997:131; Pankhurst 1965:160).

8 Religion includes theological laws and opinions. However, at the point where it intersects with politics, the way religion is interpeted and the way it is used in intersects with politics, the way religion is interpreted and the way it is used in relation to the behaviours peformed create theo-political reflections. From this perspective, it should not be forgotten that religion is politically instrumentalised and this power is used for political purposes (Urban 2005:7256-7258). 


\section{Possibilities to influence political decisions}

Theocentric or geocentric understandings are approaches that will be a disaster for humanity. Whether it is Lewis's (2007:63) approach in the West that regards Western culture as the only norm and declares it the last island of peace of humanity and that if a crisis was to be experienced here, it would be the end of all humanity, or the approach that sees people other than themselves as non-believers/polytheists; common good and life beyond Ummah will not be realised.

However, blowing the conflict by saying 'it is inevitable that there is a conflict between two claims which are historically consecutive, religiously alike, geographically close' (Lewis 2001:6) supports the previous understanding. The world should be considered as a struggle of right and superstitious thoughts or conflicting site of unbelievers, by considering oneself as a believer or deserved place, it should be discussed with a priority that attitudes of making all the rest of social parts as an object of conflict will be dealt politically.

While Serahsi, one of the Islamic scholars (b. 483/1090), explains that human has rights and liabilities, he acts with the principle of 'el-ismetubi'l Ademiyye', namely, 'the reason of dignity and inviolability is to be human' in the tradition of Islam. Serahsi states that Allah created the people to carry his trust and equipped them so as to fulfil the requirements of Allah with the mental and legal personality (liability) blessings, and again Allah granted them the rights to have inviolability (virtue), freedom (liberty) and being an owner of property (ownership) so as to pay requirement of this trust. According to Islamic scholars, having basic rights, such as living, being the owner of religion and personal conviction, marrying and reproducing, becoming the owner of property, securing honour and glory, has been based on the virtue and prophecy of being human. Ibn Abidin, one of 19th-century scholars, (b. 1252/1836) revealed his provision from these origins that '[h]uman is reverend/reputable, even if it is an unbeliever; for this reason, it is not permissible to break a bone of dead believer' (Yaman 2015:14-15).

According to this formulation of having fundamental importance in modern law, everyone has the right to live and the right of inviolability in terms of material and spiritual life. A deliberate murder is considered as killing all people and death penalty is given in return (Surah 2:178; 5:32; 17:33). In the same way, honour and dignity of people are protected by giving severe penalties for rape (Surah 24:4). The Qur'an does not let men amongst you laugh at others, nor defame or be sarcastic towards each other, nor call each other by (offensive) nicknames (Surah 49:11). This is a meaningful example of sensitivity of Islam for personal rights.

Islam legalises war only in certain situations. If they withdraw from you but fight you not, and (instead) send you (guarantees of) peace, then Allah had opened no way for you (to make war against them) (Surah 4:90). 'But if the enemy incline towards peace, do thou (also) incline towards peace, and trust in Allah' (Surah 8:61):

Allah forbids you not, with regard to those who fight you not for (your) Faith nor drive you out of your homes, from dealing kindly and justly with them: Allah only forbids you, with regard to those who fight you for (your) Faith, and drive you out of your homes, and support (others) in driving you out, from turning to them (for friendship and protection). It is such as turn to them (in these circumstances), that do wrong. (Surah 60:8-9)

When he turns his back, his aim everywhere is to spread mischief through the earth and destroy crops and cattle. But Allah loveth not mischief. (Surah 2:205; Surah 8:47; Surah 16:92; Al-Bukhari, Jihad, 15; Muslim, Imare, 149)

Islam protects human dignity and takes measures so that human rights can be ensured even in times of war. Inter alia, despite being on the side of the enemy but not fighting the woman, children, elder people, disabled people and people who are engaged in their own work and also clergymen staying in their own sanctuaries were not touched; sacraments of enemy were not touched, unnecessary devastation was banned, torture and looting were deemed as crimes, and respecting dead bodies of enemies was ordered (Al-Bukhari Jihad, 102, 149; Muslim, Jihad, 2, 3, 12; Ebu Davud, Hudud, 14; Tirmizi, Siyer, 40).

The Prophet declared that he will be in front of those who steal from non-Muslims, lay financial responsibility on them over their powers, and take something from them even if they do not find it in themselves, and stated that a person who killed a non-Muslim will not experience the smell of heaven, which is felt from a 40-year distance. The words, 'they accepted poll tax so that their goods would be our goods, their blood be like our blood', which was directed at especially Ali and many companions of prophet Muhammad, supports the above point (Kâsânî 1910:111). Based on all these instructions, Islamic jurists emphasised that non-Muslims 'should be left alone with their beliefs' within the framework of the general rule of 'they have rights and obligations just like Muslims' (Yaman 2015:22).

The Prophet did not establish a 'theocratic state' in Medina, he established a territorial state based on religious pluralism instead of a state established according to Islamic principles. With the Medina agreement, it was accepted that the city belonged to both Jews and Muslims, and both of them should join to defend the city when there would be a threat from the outside. As expressed in an article of agreement, 'all the tribes in Medina is a single Ummah separately from other people' (Afsaruddin 2007:5).

Interestingly, the word 'Ummah' used here was changed into an Islamic meaning only. Indeed, in parallel to this narrowed meaning, today Muslims use the word 'Ummah' for their religious fellows only. However, in the Medina agreement, even though 'Ummah' is connected to different religions, it meant people who create a political community within the framework of common interests. This has a 
meaning with its one direction that 'a community with the secular character of ummah of Medina led by The Prophet Muhammad' (Peters 1994:200).

When examining it in the context of Islamic political tradition, Al-Farabi tried to show an ideal dimension of living together philosophically and theologically. According to him, an ideal state 'is an egalitarian organization where people are free to do the things that they want'. Moreover, the people who live in this state, 'are thirsty citizens to approve the leadership of those who promised more freedom and opportunity' (Rosenhal 1960:100-101). According to Al-Farabi, when there is such a state encouraging freedom, 'people from different countries will immigrate here in crowds', and because of these immigrations, there will be a 'mixture of race and cultural diversity in the most ideal type', thus a suitable ground for skilled professionals to be developed (Akyol 2011:74).

\section{The production of cultural fields for life paradigm}

Andalusia is like a museum, waiting to be discovered where there are many examples of positive interaction culturally. For about four centuries in Andalus, Muslims, Christians and Jews contributed to building a common culture in a free but competitive environment by living, and they were affected by each other a lot.

In the cultural context, people are expected to respect cultural elements coming from clothing, eating, drinking and believing elements for a life beyond Ummah. Otherwise, any ridiculed cultural element results in exclusion of people naturally and reinforce the otherness identity (Jumaa 2021:62-65). The Qur'an motivates the right behaviour by warning believers of these kinds of behaviours (Surah 5:57-58).

Today, Muslim minorities in the West can be a bridge between the Muslim world and the West. These people, who live in the West, receive education, know its culture and are citizens of that country, will be able to eliminate the West's prejudice and lack of knowledge about Islam, on the one hand, and on the other hand, they can build their own ontological existence as personal and equal citizens in a non-Muslim country. In this case, they will be able to offer a model of coexistence beyond the Ummah to Muslim communities other than themselves.

As integrating to the conditions of age is perceived as approval of weakness, request for resistance and decomposition is ossified. This reaction was childish. As feeling lowly carries the potential to turn into violence. The Qur'an says 'O people!' (Enver 2017:165); because it is a book that was sent to all people with its claim. Unfortunately, the Islamic world has lost its ability to say 'O people!' in this disengagement process; unavoidably, it remained within the boundaries of the call of 'O believers!' This took Muslims into the psychology of ignoring or disregarding source and a model of living together beyond the Ummah.

\section{A religious training policy for surpassing the given paradigm or building a new paradigm}

Improving an understanding of Ummah beyond Ummah, surpassing the theological, political, socio-cultural and educational constraints of the given situation and reconstructing the principle on which the solution will be produced at least on the epistemological basis can be mentioned in terms of social, economic and socio-cultural components. However, in order for this understanding and the Convivencia to get out of being a historical 'myth' and to be realised in the world of social reality, there is undoubtedly a need for education, especially for religious education politics. The starting point of this education and/or religious education policy at the epistemological and conceptual level is the answer to the question '[w]ill we live in unity or together?'

The current paradigm is conceptually descriptive and unity oriented with its predominant language. Although the concept of 'unity' is frequently used in discourses expressing pluralism, its meaning requires prioritising the rejection of diversity and standardised understanding. This notion of unity also means ignoring differences for today. One step away from the understanding of unity is to force people or groups of different qualities to comply with established rules and structures set by considering the characteristics of the dominant groups of society (Şimşek 2016:378).

The claim of unity means that the person or any thought or belief places itself in the centre of everything, its own idea or its own thought and, thus, it is egocentric. The 'other', which is outside the 'union', is not suitable for it just because it is different. In other words, 'unity' is, in a sense, the enemy of the 'other'. This understanding, which excludes or at least considers the difference to be melted in one pot, is one of the pillars of a vaporiser and assimilative policy, which identifies itself on the basis of religion, sect and culture. However, it is not possible to talk about the existence of isolated religious and cultural identity in almost any region of the world. Moreover, similarity-based policies can increase the marginalisation (Şimşek 2016:378-379). For this reason, togetherness should be emphasised, not unity or similarity concepts.

However, the concept of 'togetherness' in a sociological sense can often be considered as a harmony between the community and the components making up that community. In other words, togetherness is used as the equivalent of the harmonious integrity of the individuals, groups, institutions and organisations that make up the community, and the functional or congruent facts (Şimşek 2016:380). Each difference is equally valuable as the others in itself. Therefore, everyone should accept and recognise each other without limits. In this context, 'togetherness' 
seeks to present an interpersonal pluralist attitude by accepting heterogeneity as a fundamental social situation and not intending to force it into the idea of a totalitarian unity. 'Togetherness', like Habermas' pluralism approach, requires different subjects to reach a common consensus with each other through a process of collaboration and interpretation (Aşlamacı 2008:92).

The fact that individuals from different cultures and lifestyles are living more and more closely together brings about economic, social, cultural and political changes or transformations. But how will people of different faiths, cultures and habits live 'together'? Many researchers seek the answer to the question of how we can live together with our differences, provided that we are both equal and free. In some of the answers given to this question, 'unity' or 'togetherness' is used, particularly in Turkey both in general and especially in the discourse of religion and religious education, and unity is used widely and extensively. However, one of the main questions to consider the concepts of unity and togetherness is that which concept is more suitable for understanding and policies that refer to pluralism (Şimşek 2016:380-381).

\section{As it is known:}

$[P]$ lurality is used to express the existence of a variety of diversity while 'pluralism' is often used to express a positive attitude towards a particular kind of plurality. In other words, taking the plurality which can also be understood as the plurality of different values, rules, world views and beliefs as a political goal brings pluralism on. Thus, pluralism, as legitimate style of a plurality in a society, refers to a situation in which different thought systems, world views, beliefs and traditions can coexist without employing hegemony one on another. (Aşlamacı 2008:16)

'In that case, it is obvious that if pluralism means the differences should be taken into consideration, the concept of togetherness must be prioritized' (Şimşek 2016:381).

If one of the main objectives of all projects and projections to be carried out in the name of this priority will be the development of this understanding and its spread amongst the masses, the most important strategic tool used is a proper religious education policy, whether formal or informal. In the end, both concepts of Ummah and the opportunities of a pluralistic social life are related to religion in one way or another, as well as the spread of related perspectives is educational.

Especially when it comes to religious education, it is rather provocative to argue that because Islam is a tawhid religion, which prioritises the concept of unity, its education based on tawhid may not be compatible with pluralism. Staying out of these arguments, it can be expressed that in the situations where at least the pluralist religious education is mentioned and where respect for differences as a value is prioritised, it is more appropriate to use 'togetherness' instead of 'unity' (Şimşek 2016:381).

\section{Conclusion}

When we look at The Qur'an, Sunnah of the Prophet and the history of İslam, it is possible to see many theoretical and practical examples about living together with members of other religions in peace.

Besides the channels which can make a life beyond Ummah possible, our understanding of traditional and historical Islamic depths will be viewed through new eyes as Muslims.

Islam widely defined the consciousness of being 'Ummah' by rejecting the nation and racial superiority (Watt 1956:241-242). We need to show that with the help of both darus sulh and darul ahd Muslims can live in peace with nonMuslims by the agreement between the two countries (darus sulh and darul ahd) to Muslims who are on the fence of dilemma of Darul Islam and Darul harp.

Whoever sees themselves in the centre of the universe in the ontological sense, except for themselves they can very easily articulate the other as barbaric, immoral and a pariah. The obstacle in front of living together is religious (JudaismIslam), as well as political (thesis of the supremacy of Western civilisation). As far as seen the thing preventing the will of living together is not produced by religions in comparison with the thoughts of the majority but the authors want to underline that the living geographical communities (Middle East-Europe) are descended from cultural, political, economic and geographical conditions.

Ignoring the fact that the discriminatory points are built by power and combinations of power, it would not be hard to be consulted with wisdom and giving priority to prosperity service. In the interaction between the 'other' and the 'near other', it is seen that all beliefs and creeds now emerge almost entirely from their own 'blessed', 'selected' and 'fatalist' islands. At a time when it becomes imperative to be together and with 'others' in the global village, it appears that it is a human duty to provide a global soul of Taarof or global convivencia ('living together').

If we are talking about the Rome-Zealot dilemma and Rome's mistakes inspired by history, it must be accepted that today is the time to review these mistakes. In order to expand unwelcoming and single-sided looks, it is expected from them to demand freedom for everyone. At the same time, the 'Zeolot-like' groups amongst Muslims should also understand this. When we say that we will establish the dominion of God, their ties with God are weakened. For this reason, it should be seen that millions of people have been hating Islam.

As a result, Küng quotes what the German Catholic Möhler said:

[T] he origin of the Qur'an, in which we often find a quite original piety, a touching devotion and a quite characteristic religious poetry, would be utterly inexplicable. It is impossible for this to 
be something artificial and forced, which would have to be assumed if we wanted to see Muhammad as a mere cheat ... Many millions of people feed and nurture a laudable religious and moral life from the Qur'an, and I do not believe that they draw from an empty spring. (Küng 2007:75)

Positive and objective, not insulting, trying to understand and respect holy things - the language of Möhler is needed more than ever today. The production and dissemination of this language are closely related to a religious education policy in the context which we try to frame in this study.

\section{Acknowledgements Competing interests}

The authors declare that they have no financial or personal relationships that may have inappropriately influenced them in writing this article.

\section{Authors' contributions}

S.K. (55\%) and Ö.G. (45\%) both contributed to the writing of this article.

\section{Ethical considerations}

This article followed all ethical standards for research study without any direct contact with human or animal subjects.

\section{Funding information}

This research work received no specific grant from any funding agency in the public, commercial or not-for-profit sectors.

\section{Data availability}

Data sharing is not applicable to this article as no new data were created or analysed in this study.

\section{Disclaimer}

The views and opinions expressed in this article are those of the author and do not necessarily reflect the official policy or position of any affiliated agency of the authors.

\section{References}

Afsaruddin, A., 2007, First Muslims: History and memory, One World Publications, Oxford. Akyol, M., 2011, Özgürlüğün Islami Yolu, Doğan Kitap, Istanbul.

Althaus, F.A., 1997, 'Female circumcision: Rite of Passageor violation of rights?', International Family Planning Perspectives 23, 130-133. https://doi. rights?, 'nternational

Arslan, H., 2010, 'Kadı Abdülcebbar'ın Hıristiyan ilahiyatına Yönelttiği Teolojik Eleştiriler', Kelam Araştırmaları 8(1), 13-44.

Aşlamacı, İ., 2008, 'Çoğulculuk ve Din Eğitimi', Unpublished MA thesis, Sakarya Üniversitesi Sosyal Bilimler Enstitüsü, Sakarya.

Aydın, M., 2009, 'Dinsel Çoğulculuğun Öteki ile Birlikte Yaşamaya Katkısı Üzerine Bazı Mülahazalar', Milel ve Nihal 6(2), 9-30.

Baş, M., 2011, 'İslam Tarihinde ve Tarihimizde Farklı Kültürlerle Birlikte Yaşama Tecrübesi', Dini Araştirmalar 14(38), 41-58.

Bulut, M.A., 2012, Ümmet, DiA, TDV Yayınları, i̇stanbul.

CFR, 2021, Global conflict tracker, viewed 27 July 2021, from https://www.cfr.org/ global-conflict-tracker/?category=us.

Çiçek, H.M., 2008, Farklı Kültürlerin Birlikte Yaşama Formülü, Beyan Yayınları, Istanbul. Courbage, Y. \& Fargues, P., 1997, Christianand Jews under Islam, I. B. Taurus, London.
Dante, A., 1998, 'ilahi Komedya', transl. R. Teksoy, Oğlak Yayıncılık, İstanbul.

Deniz, Y., 2016, 'Ortadoğu'daki Çatışmalara Devletlerin Ve Devlet Dışı Aktörlerin Etkileri', Tesam Akademi Dergisi - Turkish Journal of TESAM Academy Ocak 3(1), 129-149.

Diamant, J., 2019, 'The countries with the 10 largest Christian populations and the 10 largest Muslim populations', Pew Research Center, viewed 27 July 2021, from https://www.pewresearch.org/fact-tank/2019/04/01/the-countries-with-the-10largest-christian-populations-and-the-10-largest-muslim-populations/.

Emin, E., 2018, İslamofobi ve İslamohobi Arasında Bat, Insamer, viewed 27 July 2021, from https://insamer.com/tr/islamofobi-ve-islamohobi-arasinda-bati_1316.html.

Enver, B., 2017, 'Kur'an'da Geçen "ey İnsanlar" ve "ey İman Edenler" Hitaplariyla Başlayan Ayetler Arasinda Bir Mukayese', Tokat ilmiyat Dergisi 5(1).

Esen, M., 2010, 'Kur'an'ın Ehl-i Kitaba Bakışı', Ankara Üniversitesi Ilahiyat Fakültesi Dergisi 51(1), 93-110. https://doi.org/10.1501/llhfak_0000001016

Faruki, I.R., 2011, islam ve Diğer inançlar, İnsan Yayınları, Istanbul.

Fuller, G., 2010, A world without Islam, Little Brown, New York, NY.

Hasan, R., 2006, 'Globalisation's challenge to the Islamic "Ummah"', Asian Journal of Social Science 34(2), 311-323. https://doi.org/10.1163/156853106777371184

Head, T. \& Landes, R., 1992, The peace of God social violence and religious response in France around the Year 1000, Cornell University Press, Ithaca, NY.

Hillgarth, J.N., 1985, 'Spanish historiography and Iberian reality', History and Theory 24(1), 23-43. https://doi.org/10.2307/2504941

Horton, R., 1960, 'A definition of religion and its uses', Journal of the Royal Anthropological Institute 90, 201-226. https://doi.org/10.2307/2844344

ibn Hişâm, 1955, es-Sirretünn-Nebeviyye, Darul Hikme, Beirut.

IEP, 2020, Global Terrorism Index 2020, Institute for Economics \& Peace, viewed 27 July 2021, from https://reliefweb.int/sites/reliefweb.int/files/resources/GTI2020-web-2.pdf

Jumaa, K.A., 2021, Ummah a new paradigm for a global world, Sunny Press, State University of New York Press, Albany, NY.

Kalın, I., 2007, islam ve Bat, TDV Yayınları, Istanbul.

Kâsânî, 1910, Bedâi'u's-sanâi fî tertíbi'ş-şerâ'i, vol. I-VII, Kahire, s.I.

Kazıcı, Z., 1998, Osmanlı Devleti’nde Dini Hoşgörü, Kültürlerarası Diyalog Sempozyumu, İstanbul Büyükşehir Belediyesi Yayınları, Istanbul.

Kipling, R., 1865-1936, The Ballad of East and West, viewed 29 November 2020, from, http://www.bartleby.com/246/1129.html.

Küng, H., 2007, Islam: Past, present and future, One World Publications, Oxford.

Lecker, M., 2004, Constitution of Medina: Muhammad's First Legal Document, Darwin Press, Princeton, NJ.

Lewis, B., 2001, Muslim discovery of Europe, W. W. Norton \&Company, New York, NY. Lewis, B., 2003, The crisis of Islam: Holy war and unholy terror, Weidenfeld-Nicolson, London.

Lewis, B., 2007, 'Çatışan Kültürler', transl. Nurettin Elhüseyni, Tarih Vakfi Yayınları, İstanbul.

Miras, K., 1984, Tecrid-i Sarih Tercümesi ve Şerhi, DiB Yayınları, Ankara.

Munt, H., 2014, The holy city of Madina sacred space in Early Islamic Arabia, Cambridge University Press, London.

Newman, Y. \& Silvan, G., 1980, Judaism A-Z: Lexicon of terms and concepts, Department for Torah Education and Culture in the Diaspora of the World Zionist Organization, Jerusalem.

Okuyan, A., 2008, 'Tarihî Belgeler Işı̆̆ında Diğer İnanç Toplumlarıyla Birlikte Yaşamaya Dair Bazı Tarihsel Kanıtlar', Dinbilimleri Akademik Araştirma Dergisi 8(3), 159-171.

Özdemir, M., 1992, 'Endülüs'te Birlikte Yașama Tecrübesi Üzerine Bazı Mülahazalar', in VIII-XI, Yüztıllar Arası (ed.), islam ve Demokrasi Kutlu Doğum Sempozyumu, vol. 291, pp. 85-93, Türkiye Diyanet Vakfi Yayınları, Ankara.

Özdemir, M., 1997, 'Endülüs'ün Yıkılış Sürecinde Öne Çıkan Bazı Hususlar', Ankara Üniversitesi Illahiyat Fakültesi Dergisi 36(1), 233-254. https://doi.org/10.1501/ Ilhfak 0000000868

Öztürk, Y.N., 2011, Kur'an'ın Temel Kavramları, Yeni Boyut Yayınları, Istanbul.

Pankhurst, R., 1965, 'A historical examination of traditional Ethiopian medicine', Ethiopian Medical Journal 3, 157-172.

Peters, E.F., 1994, Muhammad and the Origins of Islam, State University of New York Press, Albany, NY.

Rahner, K., 1974, 'Anonymous and explicit faith', in Theological Investigations, transl. D. Bourke, Seabury Press, New York, NY.

Rosenhal, F., 1960, The Muslim concept of freedom prior to the nineteen century, Brill, Leidin.

Sarıkaya, M.E., 2020, 'Sosyal Çatışma ve Din: Matürîlî Düşüncede İzdüşümleri Üzerine Bir İnceleme', Bingöl Üniversitesi Ilahiyat Fakültesi Dergisi 16, 356-369. https:// doi.org/10.34085/buifd.810415

Sezgin, F., 2011, 'Islam'in Bilimler Tarihindeki Yaratici Yerine Bir Bakis', Adam Akadem Journal 1, pp. 89-98.

Şimşek, E., 2016, 'Türkiye'de Din Eğitimi ve Dini Çoğulculuk: Birlikte mi, Beraber mi?', in M. Okumuşlar (ed.), Dini Araştirmalar ve Küresel Barış, Uluslararası Din Araştirmalar ve Küresel Barış Sempozyumu, vol. II, pp. 371-384, Türkiye İmam Hatipliler Vakfi Yayınları, Konya.

Stedman, E.C., 1895, A Victorian anthology, Riverside Press, Cambridge. 
UNWTO, 2019, International tourism highlights, viewed 27 July 2021, from https:// www.e-unwto.org/doi/pdf/10.18111/9789284421152.

Urban, H.B., 2005, 'Politics and religion', in L. Jones (ed.), Encyclopedia of religion 2nd edn., Macmillan, Detroit, MI.

Ünal, M., 2016, 'Vasat Ümmet Olabilmek', Diyanet Aylık Dergi, vol. 305, s.n., s.I.

Ünalan, S. \& Öztürk, H., 2007, ‘Hz. Muhammed'in Hıristiyanlarla Yapmış Oldugu Diplomatik Münasebetlerin Evrensel Boyutu', Firat Üniversitesi Ilahiyat Fakültesi Dergisi 12(2), 11-31.
Watt, M., 1956, Muhammad at Madina, Oxford University Press, London.

Yaman, A., 2015, 'İslam'ın Temel Kaynakları ve Tarihî Tecrübe Işı̆̆ında Gayri Müslimlerle Birlikte Yaşamanın Hukukî Çerçevesi', Necmettin Erbakan Universitesi Illahiyat Fakültesi Dergisi 40, 9-36.

Yavuz, Ş., 2009, “'Öteki” ile "Beriki” Arasındaki Salınımda Dinlerde Birlikte ve Beraber Yaşamanın Teolojik ve Pratik İmkânı', Milel ve Nihal 6(2), 31-50.

Yılmaz, M.N., 1998, 'İslam ve Dinler Arası Birlikte Yaşama', Diyanet IIlmi Dergi 34(2), 3-19. 